\title{
Evaluation of Antioxidant Activity and Some Secondary Metabolites of Purple Coneflower (Echinacea purpurea L.) in Response to Biological and Chemical Fertilizers
}

\author{
Reza Isazadeh Hajagha ${ }^{1}$, Leila Tabrizi ${ }^{2}$, Ebru Kafkas $^{3} \&$ Saliha Kırıc $^{4}$ \\ ${ }^{1}$ Department of Agronomy, Ministry of Agriculture, Jahad, Tehran, Iran \\ ${ }^{2}$ Department of Horticultural Sciences, Faculty of Agricultural Science and Engineering, College of Agriculture \\ and Natural Resources, University of Tehran, Karaj, Iran \\ ${ }^{3}$ Department of Horticulture, Faculty of Agriculture, University of Cukurova, Turkey \\ ${ }^{4}$ Department of Field Crops, Faculty of Agriculture, University of Cukurova, Turkey \\ Correspondence: Reza Isazadeh Hajagha, Department of Agronomy, Ministry of Agriculture Jahad, Tehran, Iran. \\ Tel: 98-914-312-9244. E-mail: isazadeh.reza52@gmail.com
}

Received: June 12, 2019

doi:10.5539/jas.v11n17p1
Accepted: July 29, 2019 Online Published: October 15, 2019

URL: https://doi.org/10.5539/jas.v11n17p1

\begin{abstract}
Purple coneflower (Echinacea pupurea L.) is an ornamental-medicinal plant belonging to Asteraceae family. It has long been used as an herbal medicine. In order to study the effects of biological and chemical fertilizers on quantitative and qualitative yields of purple coneflower, an experiment was conducted at Department of Horticultural Science and Landscape, University of Tehran. The trial was arranged based on a randomized complete block design, with eight treatments and three replications. Treatments were included control (no fertilizers), nitrogen-fixing, bacteria: Azospirillum lipoferum (AL), Azotobacter chrococum (AC), phosphorus solubilizing bacterium Pseudomonas fluorecens, (PF), Glomus intrradices inoculum (GI), the mixture of the three bacteria and the mixture of the three bacteria plus the mycorrhizal inoculum. According to the results of HPLC, Catechin content was high at herbage in both years. In addition, the best results have been taken from the $\mathrm{AL}$ and $\mathrm{AC}$ with the control. Caffeic acid, chlorogenic acid and Epicatechin contents were higher during the first year of the herbage, and control, AC and AL treatments gave high value. Ferulic acid was high in the herbage during the first year and generally high values were obtained from PF and GI treatments. Quercetin content was high in plant root during the first year with $\mathrm{AC}$ application.
\end{abstract}

Keywords: biological fertilizers, coneflower, phenolics, caffeic acid

\section{Introduction}

Purple coneflower (Echinacea pupurea L.) is an herbaceous-perennial plant that is native to North America and grows in northern part of the Missouri River (Bodinet et al., 2002). The active components present in the root and herb of various species of Echinacea display antifungal, antibacterial and antiviral activities, which are exploited in the production of drugs used to prevent colds and respiratory diseases. The active ingredients of various Echinacea species also boost the immune system by promoting the production of immunoglobulin in the blood (Omidbeigi, 2013). Shoots and roots of coneflower contain valuable active substances, belonging to various chemical groups. The most important of them are caffeic acid and its derivatives, alkyl amide compounds, polysaccharides and essential oils. Cichoric acid and echinacoside are present in various Echinacea species. E. purpurea has been reported to have a high level of cichoric acid, is found at even $4.5 \%$ (Bauer \& Remiger, 1989). Over the past few decades, the application of chemical materials in agriculture has led to several environmental issues such as contamination of water sources, inferior quality of agricultural crops, reduced biodiversity, genetic erosion, pest resistance, and reduced soil fertilization (Sharma, 2002). The value of medicinal plants depends upon their quality, and these plants require a lower amount of fertilizers in comparison with most agronomic and horticultural crops, their cultivation is low-input, sustainable ecosystems could, in addition to protect environmental health, assuring their quality, thereby eliminating the negative influences of chemical inputs (Tabrizi, 2007). One of major aspects of sustainable agriculture is the use of biological fertilizers in order to eliminate or reduce the use of chemical inputs (Sharma, 2002). The integrated use of biological and 
non-biological fertilizers is the best managing strategy to improve yields as well as phytochemical quality in medicinal plants (Malik et al., 2011). Exploiting rhizobacteria and mycorrhizal fungi is a good strategy for producing medicinal plants. Although these microorganisms are present in the soil, they are often available in an insufficient amount for competing with other microorganisms commonly present in the rhizosphere. Therefore, to being useful in agriculture, it is important to inoculate plants with existence of these microorganisms. Although a considerable number of plant growth-promoting microorganisms are economically used for improving agricultural yields (Subba, 1993), little information is available about their use in production of medicinal plants (Kapoor et al., 2002; Khaosaad et al., 2006). Integrated management of organic and inorganic fertilizers is the best strategy that can be applied for increasing yields and active components of medicinal crops. In fact, medicinal plant cultivation requires precise balance in use of organic, inorganic, and biological fertilizers (Malik et al., 2011). Rhizobia inoculation of plants can be good alternative for chemical fertilizers to increase plant growth and yield. However, its effect on the secondary metabolites has not been very well studied or is not very well known (Banchio et al., 2010). Mycorrhizae also increase seedling tolerance to drought, high temperatures, infection of pathogenic fungi, and even high soil acidity (Chen, 2006).

Hence, this study was done to compare the biological and chemical fertilizer's effects on some secondary metabolites of purple coneflower.

\section{Material and Methods}

\subsection{Plant Material and Experimental Location}

The purple coneflower's seeds were obtained from Medicinal Plants Section, Field Crops Department, Faculty of Agriculture, University of Çukurova, Adana/Turkey. A two-year experiment was conducted at Horticultural Research Station, Department of Horticulture, University of Tehran, Karaj, Iran. The trial was arranged in a randomized complete block design with eight treatments and three replications per treatment. The physical and chemical properties of the soil of experiment area are shown in Table 1. Based on the meteorological data the experimental location, the hottest month in Karaj was July, 2010 when the temperature was $36.98{ }^{\circ} \mathrm{C}$. The coldest recorded temperature was on January, as $-3.86^{\circ} \mathrm{C}$. The total amount of monthly rainfall varied between 4.1 and $62.6 \mathrm{~mm}$.

Table 1. Chemical and physical properties of the soil

\begin{tabular}{|c|c|c|c|c|c|c|c|c|c|c|}
\hline Sampl & $\mathrm{pH}$ & $\mathrm{EC}(\mathrm{dS} \mathrm{m})$ & OC (\%) & $\mathrm{N}(\%)$ & $\mathrm{P}(\mathrm{mg} / \mathrm{kg})$ & $\mathrm{K}(\mathrm{mg} / \mathrm{kg})$ & Texture & Sand (\%) & Silt (\%) & Clay (\%) \\
\hline Soil & 7.78 & 2.68 & 1.19 & 0.12 & 28.6 & 360 & Loam & 39 & 38 & 23 \\
\hline
\end{tabular}

Note. $\mathrm{EC}=$ Electrical conductivity, $\mathrm{OC}=$ Organic Carbon, $\mathrm{N}=$ Nitrogen, $\mathrm{P}=$ Phosphorus, and $\mathrm{K}=$ Potassium.

\subsection{Properties of the Chemical and Biological Fertilizers and Field Trial}

The microorganisms used in the experiment were three different bacteria species and one mycorrhizal fungus namely Glomus intraradices. Treatments included (1) control; (2) chemical fertilizer (N: urea 46\%, P: triple superphosphate, K: potassium sulphate,120-60-60 kg ha ${ }^{-1}$ respectively); (3) Azospirillum lipoferum (A.L.); (4) Azotobacter chrococum (A.C.); (5) Pseudomonas fluorecens (P.F.) (6) mycorrhizal fungus Glomus intraradices (G.I.; (7) The mixture of the three bacteria (A.L. +A.C. + P.F.); and (8) the mixture of the three bacteria plus the mycorrhizal fungus (A.L. +A.C. +P.F. +G.I.). Seed application rates of A. lipoferum, A. chrococum, P. fluorecens were $300 \mathrm{ml} \mathrm{kg}{ }^{-1}, 4000 \mathrm{ml} \mathrm{ha}^{-1}$ for root (inoculation), and G. intraradices was $200 \mathrm{~g} \mathrm{~kg}^{-1}$ for seed, $2500 \mathrm{~g} \mathrm{ha}^{-1}$ for root. Total amounts of phosphorus $\left(60 \mathrm{~kg} \mathrm{ha}^{-1}\right)$ and potassium $\left(60 \mathrm{~kg} \mathrm{ha}^{-1}\right)$ fertilizers plus half of the nitrogen $\left(60 \mathrm{~kg} \mathrm{ha}^{-1}\right)$ were added into the soil, at $0-30 \mathrm{~cm}$ of depth, during the soil preparation, and were mixed thoroughly. The other half of the nitrogen fertilizer $\left(60 \mathrm{~kg} \mathrm{ha}^{-1}\right)$ was added into the soil at stemming stage (5 August). In the second year, the chemical fertilizers were administered or provided in the same way as the first year. The trays were filled with a mixture of field soil, humus and sieved sand in a proportion of 1:1:1. In order to apply biological fertilizer treatments, the coneflower's seeds were first sterilized with sodium hypochlorite $1.5 \%$ and washed with distilled water by soaking for one hour. They were then kept and dehydrated at room conditions. After that, seeds were inoculated with each bacterial inoculum, which were prepared as a solution. For mycorrhiza inoculation (inoculum was in powder form), Arabic gum ( $20 \mathrm{~g} \mathrm{~L}^{-1}$ of water) was used. The external surface of the seeds was dehydrated in shade. Finally, they were planted in seedling trays on May 4, 2011 and were irrigated immediately. The first germination was observed one week after seeding (May 12-17, 2011). Over the time, the seedlings developed 4-6 leaves, they were kept at greenhouse conditions. Just before transplanting, the seedlings roots were treated with the relevant biological fertilizer solutions and immediately 
thereafter the seedlings were transplanted at July 23, 2011 and drip irrigated. Each plot was $15.75 \mathrm{~m}^{2}$, contained 6 rows with $50 \mathrm{~cm}$ distance between them. Each row had 14 plants $30 \mathrm{~cm}$ apart, thus, there were 84 plants in each plot. The plants were harvested on October 25, 2011 in the first year and on August 5, 2012 in the second year.

\subsection{Determination of Phenolic and Flavonoid Content}

Total phenolic and flavonoid contents were determined according to the method of Wu et al. (2008) which is a modification of Folin-Ciocalteao After preparing methanolic extracts from the roots and shoots, $100 \mathrm{ml}$ was mixed with $2.5 \mathrm{ml}$ deionized water and $0.1 \mathrm{ml}$ reagent Folin-Ciocalteao $(2 \mathrm{~N})$. After that $0.5 \mathrm{ml}$ sodium carbonate $\left(\mathrm{Na}_{2} \mathrm{CO}_{3}\right)$ solution $(20 \%)$ was also added, and the solution was mixed thoroughly for 6 min. The solution was then kept at room conditions for $30 \mathrm{~min}$, and absorption at 760 nanometers was recorded using a spectrometer device (Shimadzu, Japan UV-1650 PC). Gallic acid was used as the standard. Total flavonoid content was determined by a colorimetric method. $0.25 \mathrm{ml}$ of methanolic plant extract or $(+)$ - catechin standard solution was mixed with $1.25 \mathrm{ml}$ of distilled water, followed by the addition of $0.75 \mathrm{ml}$ of $5 \%$ sodium nitrite solution. After $6 \mathrm{~min}, 0.15 \mathrm{ml}$ of $10 \%$ aluminum chloride solution was added and the mixture was made up to $2.5 \mathrm{ml}$ with distilled water and well mixed. The absorbance was measured immediately at $510 \mathrm{~nm}$ using a spectrophotometer. The results were expressed as mean $\mathrm{mg}$ of $(+)$ - catechin equivalents per gram of plant dry matter weight for the triplicate extracts.

\subsection{Extraction and Hydrolysis Procedure of HPLC Analysis}

HPLC analysis was determined according to Koşar et al. (2004). Three grams of this powder was sold $10 \mathrm{ml}$ with distilled water. These samples were directly used for HPLC analyses. The liquid chromatographic apparatus (Hewlett-Packard HP-1100) consisted of an in-line degasser pump and controller coupled to a photodiode array detector equipped with an automatic injector (20 il injection volume) interfaced to a PC running ChemStation chromatography manager software (Hewlett- Packard). Separations were performed on a $150 \mathrm{~mm}, 4.6 \mathrm{~mm}$ i.d., 5 im. Reverse-phase Nucleosil C18 analytical column (Supelco. PA) operating at room temperature with a flow rate of $1 \mathrm{ml} / \mathrm{min}$. Detection was carried out with a sensitivity of 0.1 a.u.f.s. between the wavelengths of 200 and $600 \mathrm{~nm}$. Elution was effected using a nonlinear gradient of solvent mixture $2.5 \% \mathrm{HCOOH}$ in water (solvent A) and $2.5 \% \mathrm{HCOOH}$ in acetonitrile (solvent B). The composition of B was increased from 5 to $13 \%$ in 15 min. increased to $15 \%$ in $5 \mathrm{~min}$. and $30 \%$ in a further $5 \mathrm{~min}$ and held for $3 \mathrm{~min}$. increased to $45 \%$ in $4 \mathrm{~min}$ and held for $3 \mathrm{~min}$. increased to $90 \%$ in $5 \mathrm{~min}$ and held for $5 \mathrm{~min}$. and then returned to initial conditions in $5 \mathrm{~min}$. Components were identified by comparison of their retention times to those of authentic standards under analysis conditions.

\subsection{Quantitative Analyses}

All of the samples were directly injected to the reverse phase chromatography column after filtration; catechin, ferulic acid, caffeic acid, chlorognic acid, quercetin and epicatechin were dissolved in methanol at a concentration of $1 \mathrm{mg} / \mathrm{ml}$ and five diluted solutions from these stock solutions were used to prepared calibration curves of each standard. Three replications from each sample were used for HPLC analyses. All samples and standards were injected three times and mean values were recorded.

\subsection{Statistical Analyses}

The experimental data were analyzed using SAS software, and means were compared based on Duncan's multiple range test at $95 \%$ confidence intervals. Microsoft Excel was also used to draw charts and do some calculations. All data of two years were analyzed separately.

\section{Results}

\subsection{Total Phenolics Contents of Shoot and Root of Purple Coneflower}

The effects of the different fertilizers on total phenolics content of aerial parts in both years and on total root phenolics content in the second year were not statistically significant (Table 2). The highest total shoot phenol was recorded in the control plants in the first and the second years, and the lowest one in A.L. + A.C. + P.F. + G.I. Furthermore, there were no significant differences among the other treatments (Table 2). Mean of total phenol content in the purple coneflower's root affected significantly by the treatments in the first year. The highest total root phenol of purple coneflower in the first year was observed in A.L., which did not show any significant differences from those of A.C., P.F. and mixture of A.L. + A.C. + P.F. Moreover, the lowest total root phenol was observed in chemical fertilizer- treated plants, which did not significantly differ from those of the other plants except that of A.L. treated plants. The highest total root phenol in the second year was observed in 
the control plants, and the lowest in plants treated with A.L. + A.C. + P.F. + G.I. The other treatments showed no significant differences (Table 2).

Table 2. Mean of total phenolics (mg/g DW) in the purple coneflower's shoot and root in the first and second year as affected by the treatments

\begin{tabular}{llllll}
\hline \multirow{2}{*}{ Treatment } & \multicolumn{3}{c}{ Total phenolics } \\
\cline { 2 - 3 } \cline { 2 - 3 } \cline { 5 - 6 } & \multicolumn{2}{c}{ Shoot } & & \multicolumn{2}{c}{ Root } \\
\cline { 2 - 3 } Control & First year & Second year & & First year & Second year \\
N.P.K & 25.98 & 25.8 & & $20.3 \mathrm{~b}$ & 26.3 \\
A.L. & 25.4 & 25.6 & & $20.2 \mathrm{~b}$ & 25.7 \\
A.C. & 25.1 & 23.7 & & $24.3 \mathrm{a}$ & 25.3 \\
P.F. & 25 & 23.6 & & $22.3 \mathrm{ab}$ & 25 \\
G.I. & 24.9 & 23.2 & & $22.6 \mathrm{ab}$ & 24.5 \\
A.L.+A.C.+P.F. & 24.9 & 23.1 & & $21.1 \mathrm{~b}$ & 23.7 \\
A.L.+A.C.+P.F.+G.I. & 24.6 & 23.1 & & $20.2 \mathrm{~b}$ & 23.3 \\
F test & 23.5 & 20.1 & & $22.7 \mathrm{ab}$ & 23.2 \\
C.V. (\%) & $\mathrm{ns}$ & $\mathrm{ns}$ & & & $\mathrm{n}$ \\
\hline
\end{tabular}

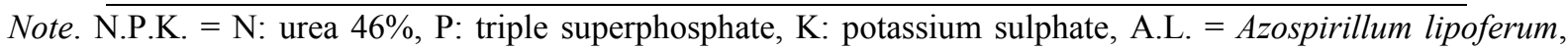
A.C. = Azotobacter chrococum, P.F. = Pseudomonas fluorecens, G.I. = Glomus intraradices, $\mathrm{ns}=$ non-significant, $*=$ Statistical significance at alpha level 0.05 , respectively, C.V. $=$ Coefficient of variation.

\subsection{Total Flavonoid Contents of Shoot and Root of Purple Coneflower}

The effects of various fertilizers on total root or shoot flavonoid content were not significant in either year of the experiment (Table 3). The highest shoot flavonoid contents of shoot and root were observed in the control plants and the lowest one in plants treated with A.L. + A.C. + P.F. + G.I.

Table 3. Mean of total flavonoid (mg/g DW) in the purple coneflower's shoot and root in the first and second years as affected by the treatments

\begin{tabular}{|c|c|c|c|c|}
\hline \multirow{3}{*}{ Treatment } & \multicolumn{4}{|c|}{ Total flavonoid } \\
\hline & \multicolumn{2}{|c|}{ Shoot } & \multicolumn{2}{|c|}{ Root } \\
\hline & First year & Second year & First year & Second year \\
\hline Control & 37.9 & 34.2 & 31.9 & 29.7 \\
\hline N.P.K & 37.8 & 32.6 & 29.6 & 29.5 \\
\hline A.L. & 36.9 & 32 & 27.7 & 29.2 \\
\hline A.C. & 35.8 & 31.8 & 27.4 & 28.5 \\
\hline P.F. & 35.4 & 31.1 & 26.2 & 28 \\
\hline G.I. & 35 & 31.1 & 26 & 27.8 \\
\hline A.L.+A.C. + P.F. & 33.8 & 30.5 & 26 & 27.4 \\
\hline A.L.+A.C.+P.F.+G.I. & 33.5 & 30.1 & 23.7 & 27.4 \\
\hline F test & ns & ns & ns & ns \\
\hline C.V. $(\%)$ & 10.05 & 11.16 & 13.91 & 8.37 \\
\hline
\end{tabular}

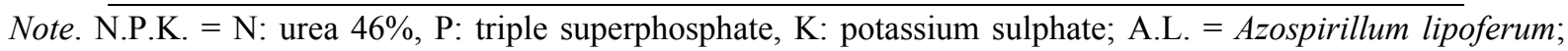
A.C. = Azotobacter chrococum, P.F. = Pseudomonas fluorecens; G.I. = Glomus intraradices, $\mathrm{ns}=$ non-significant, C.V. $=$ Coefficient of variation.

\subsection{Catechin Content of Shoot and Root of Purple Coneflower}

As shown in Table 4, the effects of different treatments on catechin concentration in purple coneflower's shoot were not significant in either year. The level of catechin in the shoot was varied between 8.75 and $11.41 \mathrm{mg} / \mathrm{g}$, in both years. The effects of treatments on root catechin concentration of purple coneflower were significant in both years (Table 4). The highest level of root catechin in the first year was observed in chemical fertilizer-treated plants, albeit with no difference from that of G.I. treated plants. However, it was significantly higher than that of 
any other treatments. The lowest root catechin level was observed in plants treated with A.L., which had, however, no significant difference from those of the treatments except for chemical fertilizer-or G.I.-treated plants. The highest root catechin level was recorded in A.L. treatment in the second year, which did not differ from chemical fertilizer, mycorrhiza, the mixture of the three bacteria, or P.F. The lowest level was recorded in plants treated with the mixture of the three bacteria, which, however, displayed no significant difference from that of the control or A.C.-treated plants.

Table 4. The mean concentration of shoot and root of Catechin $(\mathrm{mg} / \mathrm{g})$ in the first and second years as affected by various fertilizer treatments

\begin{tabular}{llllll}
\hline \multirow{2}{*}{ Treatment } & \multicolumn{3}{c}{ Catechin } \\
\cline { 2 - 3 } \cline { 2 - 3 } \cline { 5 - 6 } & \multicolumn{2}{c}{ Shoot } & & \multicolumn{2}{c}{ Root } \\
\cline { 2 - 3 } Control & 10.34 & 11.41 & & First year & Second year \\
N.P.K. & 9.13 & 9.98 & & $3.63 \mathrm{a}$ & $6.38 \mathrm{~cd}$ \\
A.L. & 10.86 & 10.35 & & $1.52 \mathrm{c}$ & $7.23 \mathrm{ab}$ \\
A.C. & 9.86 & 11.18 & & $2.19 \mathrm{bc}$ & $5.18 \mathrm{bcd}$ \\
P.F. & 8.81 & 11.35 & & $1.99 \mathrm{bc}$ & $5.87 \mathrm{abc}$ \\
G.I. & 8.86 & 10.46 & & $2.94 \mathrm{ab}$ & $6.35 \mathrm{ab}$ \\
A.L.+A.C.+P.F. & 9.06 & 10.36 & & $2.03 \mathrm{bc}$ & $6.97 \mathrm{ab}$ \\
A.L.+A.C.+P.F.+G.I. & 8.75 & 9.32 & & $2.18 \mathrm{bc}$ & $4.01 \mathrm{~d}$ \\
Ftest & $\mathrm{ns}$ & $\mathrm{ns}$ & & $* *$ & $*$ \\
C.V. $(\%)$ & 11.45 & 10.41 & & 22.03 & 15.9 \\
\hline
\end{tabular}

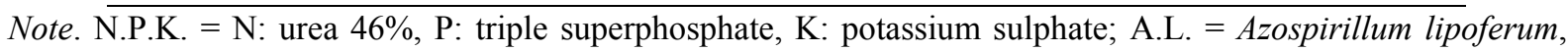
A.C. = Azotobacter chrococum, P.F. = Pseudomonas fluorecens, G.I. = Glomus intraradices, $\mathrm{ns}=$ non-significant, $* *=$ Statistical significance at alpha level 0.05 and 0.01 , respectively, C.V. $=$ Coefficient of variation.

\subsection{Caffeic Acid Content of Shoot and Root of Purple Coneflower}

The effects of different treatments on caffeic acid concentration in purple coneflower's shoot and root were significant in both years (Table 5). The highest level of caffeic acid in the shoot was observed in the control plants, albeit with no significant differences from that of A.C. or A.L. + A.C. + P.F. + G.I. The lowest level of caffeic acid in the shoot in the first year was observed in P.F. treated plant, which had, however, no significant difference from that of A.L. The highest level of caffeic acid in the shoot in the second year was recorded in the plants treated with A.C., which was not statistically different from that of the control or chemical fertilizer- or A.L. + A.C. + P.F. treated plants. The lowest level of caffeic acid in the shoot in the second year was achieved with A.L. + A.C. + P.F. and A.L., albeit with no significant difference from that of chemical fertilizers, G.I. or P.F. (Table 5). The highest level of caffeic acid of root in the first year was recorded in the control plants but with no significant difference from that of plants treated with G.I. or P.F. The lowest level of root caffeic acid in the second year was observed in A.C. treated plants, which was lower than that of any other treatment. The maximum level of caffeic acid in the root in the second year was recorded in A.C. treated plants, which did not differ from that of G.I. treated plants, however. The lowest level in the second year was found in A.L. treated plants, which was significantly different from that of any other treatment except A.C. -or G.I. treated plants (Table 5). 
Table 5. The mean concentration of shoot and root of Caffeic acid $(\mathrm{mg} / \mathrm{g})$ in the first and second years as affected by various fertilizer treatments

\begin{tabular}{|c|c|c|c|c|}
\hline \multirow{3}{*}{ Treatment } & \multicolumn{4}{|c|}{ Caffeic acid } \\
\hline & \multicolumn{2}{|c|}{ Shoot } & \multicolumn{2}{|c|}{ Root } \\
\hline & First year & Second year & First year & Second year \\
\hline Control & $30.78 \mathrm{a}$ & $13.54 \mathrm{ab}$ & $16.81 \mathrm{a}$ & $11.24 \mathrm{bc}$ \\
\hline N.P.K. & $24.01 \mathrm{~cd}$ & $12.43 \mathrm{abc}$ & $11.76 \mathrm{bc}$ & $10.47 \mathrm{c}$ \\
\hline A.L. & $21.22 \mathrm{de}$ & $10.48 \mathrm{c}$ & $12.33 \mathrm{bc}$ & $9.83 \mathrm{c}$ \\
\hline A.C. & $29.64 \mathrm{a}$ & $14.52 \mathrm{a}$ & $8.16 \mathrm{~d}$ & $14.62 \mathrm{a}$ \\
\hline P.F. & $19.61 \mathrm{e}$ & $12.58 \mathrm{abc}$ & $14.37 \mathrm{ab}$ & $10.36 \mathrm{c}$ \\
\hline G.I. & $25.04 \mathrm{bc}$ & $11.85 \mathrm{bc}$ & $16.55 \mathrm{a}$ & $13.20 \mathrm{ab}$ \\
\hline A.L.+A.C.+P.F. & $23.44 \mathrm{~cd}$ & $14.47 \mathrm{ab}$ & $12.90 \mathrm{bc}$ & $10.28 \mathrm{c}$ \\
\hline A.L.+A.C.+P.F.+G.I. & $27.86 \mathrm{ab}$ & $10.24 \mathrm{c}$ & $11.12 \mathrm{c}$ & $10.96 \mathrm{bc}$ \\
\hline Ftest & $* *$ & $*$ & $* *$ & $* *$ \\
\hline C.V. $(\%)$ & 7.37 & 10.93 & 11.05 & 12.08 \\
\hline
\end{tabular}

Note. N.P.K. $=\mathrm{N}$ : urea 46\%, P: triple superphosphate, K: potassium sulphate, A.L. $=$ Azospirillum lipoferum, A.C. $=$ Azotobacter chrococum, P.F. $=$ Pseudomonas fluorecens, G.I. $=$ Glomus intraradices, $*$ and $* *=$ Statistical significance at alpha level 0.05 and 0.01 , respectively, C.V. = Coefficient of variation.

\subsection{Chlorogenic Acid Content of Shoot and Root of Purple Coneflower}

With regard to Table 6, variance analysis showed that the effects of different treatments on chlorogenic acid in the shoot and root were significant in both years. The results showed that the highest chlorogenic acid level in the shoot in the first year was recorded in the control plants, which had, however, no significant difference from A.L. + A.C. + P.F. + G.I. or A.C. The lowest level of shoot chlorogenic acid was recorded in A.L. treated plants (Table 6). The level of shoot chlorogenic acid in the second year was considerably lower than the values of the first year, regardless of the treatment. The highest level of shoot chlorogenic acid in the second year was recorded in A.C. treated plants, which had, however, no significant difference from that of the control or chemical fertilizer or A.L. + A.C. + P.F. treated plants. The lowest level was recorded in A.L. treated plants, albeit with no significant difference from that of P.F., G.I., or A.L. + A.C. + P.F. + G.I. (Table 6). The highest level of chlorogenic acid of root in the first year was observed in G.I. treated plants, which did not significantly differ from that of the control, chemical fertilizer and PF treated plants. The lowest level $(13.20 \mathrm{mg} / \mathrm{g})$ was found in plants treated with A.C., which was lower than that of any other treatment (Table 6). The highest level of root chlorogenic acid in the second year $(23.85 \mathrm{mg} / \mathrm{g})$ was found in A.C. treated plants, which had, however, no significant difference from that of the control or G.I. treated plants. The lowest level $(15.53 \mathrm{mg} / \mathrm{g}) \mathrm{was}$ observed in chemical fertilizer-treated plants, which had, however, no significant difference from that of A.L. + P.F. + G.I. or A.L. + A.C. + P.F. + G.I. treated plants.

Table 6. The mean concentration of shoot and root of Chlorogenic acid $(\mathrm{mg} / \mathrm{g})$ in the first and second years as affected by various fertilizer treatments

\begin{tabular}{llllll}
\hline \multirow{2}{*}{ Treatment } & \multicolumn{3}{c}{ Chlorogenic acid } \\
\cline { 2 - 3 } \cline { 2 - 3 } \cline { 5 - 6 } & \multicolumn{2}{c}{ First year } & Second year & & \multicolumn{2}{c}{ Foot } \\
\hline Control & $30.78 \mathrm{a}$ & $13.54 \mathrm{ab}$ & & $16.81 \mathrm{a}$ & $11.24 \mathrm{bc}$ \\
N.P.K. & $24.01 \mathrm{~cd}$ & $12.43 \mathrm{abc}$ & & $11.76 \mathrm{bc}$ & $10.47 \mathrm{c}$ \\
A.L. & $21.22 \mathrm{de}$ & $10.48 \mathrm{c}$ & & $12.33 \mathrm{bc}$ & $9.83 \mathrm{c}$ \\
A.C. & $29.64 \mathrm{a}$ & $14.52 \mathrm{a}$ & & $8.16 \mathrm{~d}$ & $14.62 \mathrm{a}$ \\
P.F. & $19.61 \mathrm{e}$ & $12.58 \mathrm{abc}$ & & $14.37 \mathrm{ab}$ & $10.36 \mathrm{c}$ \\
G.I. & $25.04 \mathrm{bc}$ & $11.85 \mathrm{bc}$ & & $16.55 \mathrm{a}$ & $13.20 \mathrm{ab}$ \\
A.L.+A.C.+P.F. & $23.44 \mathrm{~cd}$ & $14.47 \mathrm{ab}$ & & $12.90 \mathrm{bc}$ & $10.28 \mathrm{c}$ \\
A.L.+A.C.+P.F.+G.I. & $27.86 \mathrm{ab}$ & $10.24 \mathrm{c}$ & & $11.12 \mathrm{c}$ & $10.96 \mathrm{bc}$ \\
Ftest & $* *$ & $*$ & & $* *$ & $* *$ \\
C.V. (\%) & 7.37 & 10.93 & & 11.05 & 12.08 \\
\hline
\end{tabular}

Note. $\mathrm{N} . \mathrm{P} . \mathrm{K}=\mathrm{N}$ : urea 46\%, P: triple superphosphate, K: potassium sulphate, A.L. = Azospirillum lipoferum, A.C. $=$ Azotobacter chrococum, P.F. $=$ Pseudomonas fluorecens, G.I. $=$ Glomus intraradices, ${ }^{*}$ and $* *=$ Statistical significance at alpha level 0.05 and 0.01 , respectively, C.V. $=$ Coefficient of variation. 


\subsection{Ferulic Acid Content of Shoot and Root of Purple Coneflower}

Variance analysis showed that the effects of various treatments on ferulic acid concentration of shoot in the first year were significant (but significant in the second year) (Table 7). The highest level of ferulic acid in the shoot in the first year was observed in P.F. treated plants, although it has no significant difference from that of G.I. or A.C. The lowest level in the first year was recorded in chemical fertilizer treated plants which was significantly lower than that of any other treatment (except $\mathrm{AL}$ and mixture of tree treatment). The level of ferulic acid in shoot in the second year was no significantly different among various treatments, but it was notably lower in the second year. As shown in Table 7, variance analysis indicated that the effects of various fertilizer treatments on root ferulic acid concentration was significant in both years. Root ferulic acid concentration in the first and second year was lower than $1 \mathrm{mg} / \mathrm{g}$. In the first year, the highest level was observed in G.I. treated plants, which was significantly higher than that of any other treatment. The lowest level was detected in A.C. treated plants, which had, however, no significant difference compared to A.L. or P.F. treated plants (Table 7).

Table 7. The mean concentration of shoot and root of Ferulic acid $(\mathrm{mg} / \mathrm{g})$ in the first and second years as affected by various fertilizer treatments

\begin{tabular}{llllll}
\hline \multirow{2}{*}{ Treatment } & \multicolumn{3}{c}{ Ferulic acid } \\
\cline { 2 - 3 } & \multicolumn{2}{c}{ Shoot } & & \multicolumn{2}{c}{ Root } \\
\cline { 2 - 3 } \cline { 5 - 6 } Control & First year & Second year & & First year & Second year \\
N.P.K. & $1.44 \mathrm{c}$ & 0.61 & & $0.29 \mathrm{~cd}$ & $0.19 \mathrm{a}$ \\
A.L. & $0.32 \mathrm{~d}$ & 0.77 & & $0.34 \mathrm{bc}$ & $0.19 \mathrm{a}$ \\
A.C. & $1.60 \mathrm{c}$ & 0.57 & & $0.28 \mathrm{~cd}$ & $0.16 \mathrm{bc}$ \\
P.F. & $2.57 \mathrm{ab}$ & 0.69 & & $0.24 \mathrm{~d}$ & $0.19 \mathrm{a}$ \\
G.I. & $2.94 \mathrm{a}$ & 0.71 & & $0.30 \mathrm{~cd}$ & $0.17 \mathrm{ab}$ \\
A.L.+A.C.+P.F. & $2.85 \mathrm{a}$ & 0.63 & & $0.59 \mathrm{a}$ & $0.19 \mathrm{a}$ \\
A.L.+A.C.+P.F.+G.I. & $1.70 \mathrm{c}$ & 0.43 & & $0.34 \mathrm{bc}$ & 0.05 \\
Ftest & $1.99 \mathrm{bc}$ & 0.67 & & $0.40 \mathrm{~b}$ & $0.14 \mathrm{c}$ \\
C.V. $(\%)$ & $* *$ & $\mathrm{~ns}$ & & $* *$ & $* *$ \\
\hline
\end{tabular}

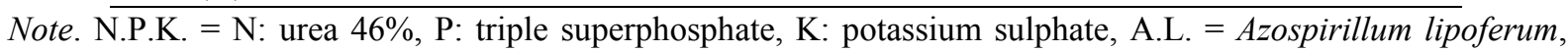
A.C. = Azotobacter chrococum, P.F. = Pseudomonas fluorecens, G.I. = Glomus intraradices, $\mathrm{ns}=$ non-significant, $* *=$ Statistical significance at alpha level 0.05 and 0.01 , respectively, C.V. $=$ Coefficient of variation.

\subsection{Epicatechin Content of Shoot and Root of Purple Coneflower}

As shown in Table 8, the effects of different treatments on shoot epicatechin in the first year, it differed from 11.55 to $12.86 \mathrm{mg} / \mathrm{g}$, which was considerably higher than that in the second year. The highest shoot epicatechin level in the second year $(9.51 \mathrm{mg} / \mathrm{g})$ was observed in chemical fertilizer treated plants, albeit with no significant difference from that of the control or P.F. treated plants. The lowest level of shoot epicatechin $(4.18 \mathrm{mg} / \mathrm{g}) \mathrm{was}$ recorded in plants treated with the mixture of the three bacteria, which had, however, no significant difference from that of A.L. + A.C., or A.L. + A.C. + P.F. + G.I. (Table 8). Variance analysis indicated that the level of epicatechin in purple coneflower's root was, in both years, significantly influenced by the treatments (Table 8). Root epicatechin concentration in the first year was lower than $1 \mathrm{mg} / \mathrm{g}$, and the highest level was recorded in A.C. treated plants, which had, however, no significant difference from that of any other treatment. The lowest level in the first year was detected in the control plants, which had, however, no significant difference from that of P.F. treated plants but with a significant difference from that of any other treatment. The lowest level in the first year was detected in the control plants, which had, however, no significant difference from that of G.I. or A.L. + A.C. + P.F. treated plants. As shown in Table 8, the level of epicatechin in the root in the second year was considerably higher than that in the first year. A.L. + A.C. + P.F. treated plants, with $6.25 \mathrm{mg} / \mathrm{g}$ epicatechin, had the highest root epicatechin level. However, chemical fertilizer treated plants, with $0.26 \mathrm{mg} / \mathrm{g}$, had the lowest level, which was not significantly different from that of P.F., G.I., or A.L. + A.C. + P.F. treated plants. 
Table 8. The mean concentration of shoot and root of Epicatechin $(\mathrm{mg} / \mathrm{g})$ in the first and second years as affected by various fertilizer treatments

\begin{tabular}{llllll}
\hline \multirow{2}{*}{ Treatment } & \multicolumn{3}{c}{ Epicatechin } \\
\cline { 2 - 3 } \cline { 2 - 3 } \cline { 5 - 6 } & \multicolumn{3}{c}{ Shoot } & \multicolumn{2}{c}{ Root } \\
\cline { 2 - 3 } Control & 12.86 & $8.08 \mathrm{ab}$ & & $0.46 \mathrm{~d}$ & $4.16 \mathrm{c}$ \\
N.P.K. & 11.7 & $9.51 \mathrm{a}$ & & $0.69 \mathrm{bc}$ & $0.26 \mathrm{e}$ \\
A.L. & 12.86 & $6.54 \mathrm{bc}$ & & $0.71 \mathrm{bc}$ & $5.05 \mathrm{~b}$ \\
A.C. & 11.87 & $6.13 \mathrm{bc}$ & & $0.91 \mathrm{a}$ & $4.57 \mathrm{bc}$ \\
P.F. & 11.55 & $9.47 \mathrm{a}$ & & $0.85 \mathrm{ab}$ & $0.58 \mathrm{de}$ \\
G.I. & 12.27 & $6.99 \mathrm{ab}$ & & $0.58 \mathrm{~cd}$ & $1.34 \mathrm{~d}$ \\
A.L.+A.C.+P.F. & 12.67 & $4.18 \mathrm{c}$ & & $0.65 \mathrm{~cd}$ & $6.25 \mathrm{a}$ \\
A.L.+A.C.+P.F.+G.I. & 12.38 & $6.03 \mathrm{bc}$ & & $0.68 \mathrm{bc}$ & $0.53 \mathrm{de}$ \\
Ftest & $\mathrm{ns}$ & $* *$ & & $* *$ & $* *$ \\
C.V. (\%) & 14.39 & 19.72 & & 14.11 & 16.25 \\
\hline
\end{tabular}

Note. N.P.K. $=\mathrm{N}$ : urea 46\%, P: triple superphosphate, K: potassium sulphate, A.L. = Azospirillum lipoferum, A.C. = Azotobacter chrococum, P.F. = Pseudomonas fluorecens, G.I. = Glomus intraradices, $\mathrm{ns}=$ non-significant, $* *=$ Statistical significance at alpha level 0.05 and 0.01 , respectively, C.V. $=$ Coefficient of variation.

\subsection{Quercetin Content of Shoot and Root of Purple Coneflower}

The effects of various treatments on the level of quercetin in purple coneflower's shoot and root were significant in both years (Table 9). The highest level of quercetin in the shoot $(42.88 \mathrm{mg} / \mathrm{g})$ was recorded in the plants treated with the single application of mycorrhiza, which had, however, no significant difference from that of A.L. + A.C. + P.F. + G.I.-treated plants. The lowest level of quercetin observed in A.L. treated plants, which had, nevertheless, no significant difference from that of chemical fertilizer or A.C. treated plants. The highest level of shoot quercetin $(33.65 \mathrm{mg} / \mathrm{g})$ in the second year was observed in the control plants, which was significantly higher than that of any other treatment. The lowest level $(18.83 \mathrm{mg} / \mathrm{g})$ was observed in A.C. treated plants, which significantly differed from those of the other treatments except the control and A.L. treated plants (Table 9). The highest level of quercetin in the root in the first year was detected in A.C. treated plants, which had, however, no significant difference from that of G.I. treated plants. The lowest level was observed in chemical fertilizer treated plants, albeit with no significant difference from that of the control or A.L. treated plants. The highest level of quercetin in the root in the second year $(53.70 \mathrm{mg} / \mathrm{g})$ was found in plants treated with the mixture of the three bacteria plus mycorrhiza (A.L. + A.C. + P.F. + G.I.), which was higher than that of any other treatment. The lowest level of quercetin in the root in the second year was, similarly, observed in chemical fertilizer treated plants, which had, however, no significant difference from that of P.F. or G.I. treated plants (Table 9).

Table 9. The mean concentration of shoot and root of Quercetin $(\mathrm{mg} / \mathrm{g})$ in the first and second years as affected by various fertilizer treatments

\begin{tabular}{llllll}
\hline \multirow{2}{*}{ Treatment } & \multicolumn{3}{c}{ Quercetin } \\
\cline { 2 - 3 } \cline { 2 - 3 } \cline { 5 - 6 } & \multicolumn{3}{c}{ Shoot } & & \multicolumn{2}{c}{ Root } \\
\cline { 2 - 3 } Control & $31.71 \mathrm{bcd}$ & $33.65 \mathrm{a}$ & & 39.46 & $30.00 \mathrm{~cd}$ \\
N.P.K. & $28.02 \mathrm{~cd}$ & $24.32 \mathrm{bc}$ & & $32.78 \mathrm{~d}$ & $23.15 \mathrm{e}$ \\
A.L. & $25.87 \mathrm{~d}$ & $26.14 \mathrm{~b}$ & & $35.97 \mathrm{~d}$ & $33.48 \mathrm{c}$ \\
A.C. & $30.17 \mathrm{bcd}$ & $18.83 \mathrm{c}$ & & $83.08 \mathrm{a}$ & $48.58 \mathrm{~b}$ \\
P.F. & $34.16 \mathrm{bc}$ & $21.22 \mathrm{bc}$ & & $55.23 \mathrm{c}$ & $26.85 \mathrm{de}$ \\
G.I. & $42.88 \mathrm{a}$ & $19.82 \mathrm{c}$ & & $75.88 \mathrm{a}$ & $27.20 \mathrm{de}$ \\
A.L.+A.C.+P.F. & $33.82 \mathrm{bc}$ & $19.79 \mathrm{c}$ & & $54.57 \mathrm{c}$ & $28.79 \mathrm{~cd}$ \\
A.L.+A.C.+P.F.+G.I. & $37.06 \mathrm{ab}$ & $23.31 \mathrm{bc}$ & & $66.17 \mathrm{~b}$ & $53.70 \mathrm{a}$ \\
Ftest & $* *$ & $* *$ & & $* *$ & $* *$ \\
C.V. $(\%)$ & 12.18 & 12.19 & & 9.31 & 8.20 \\
\hline
\end{tabular}

Note. N.P.K. $=\mathrm{N}$ : urea 46\%, P: triple superphosphate, K: potassium sulphate; A.L. $=$ Azospirillum lipoferum, A.C. $=$ Azotobacter chrococum, P.F. $=$ Pseudomonas fluorecens, G.I. $=$ Glomus intraradices, $* *=$ Statistical significance at alpha level 0.05 and 0.01 , respectively, C.V. $=$ Coefficient of variation. 


\section{Discussion and Conclusions}

The main caffeic acid derivative (caftaric acid, chlorogenic acid and echinacoside) in EA and EPA, has been functionally linked to anti-inflammatory and wound healing properties of Echinacea when applied topically. Caffeic acid derivatives are effective antioxidants in free radical generation systems (Kumar \& Ramaiah, 2011). Aghalikhani et al. (2013) in studies on Echinacea purpuea reported that the highest level of phenolic compounds was detected in plants treated with neutrogen chemical fertilizers plus nitroxin. They stated that this increased content of phenolics might be attributed to the higher availability of nitrogen to the plant. Berbec at al. (1998) reported that improved nutrition status could increase phenolic acid compounds in E. purpurea. El-Sayed et al. (2012) found that the improved nutrition (such as N and K levels) could increase cafeic acid content of $E$. paradoxa. Biological fertilizers such as plant growth-promoting bacteria and mycorrhizal fungi could improve chemical compounds by increasing the uptake of nutrients. Generally, biological fertilizers increase nutrient absorption by plant, phytohormones synthesis, and control of plant pathogens, thereby improving the overall performance of plants. Montanari et al. (2008) reported that feeding nitrogen in the form of nitrate significantly increased the amount of chlorogenic acid, echinacoside and chicoric acid in root of Echinacea angustifolia. According to Taie et al. (2008), application of organic and biological fertilizers in soybean plants, increased significantly the total phenolics, total flavonoids, caffeic acid, chlorogenic acid and quercetin in comparison with the control treatment. Sharma (2002) stated that the amount of phenolic compounds such as chlorogenic acid, ferulic acid and gallic acid was increased in comparison with control, by application of the growth promoting bacteria (Pseudomonas fluorescens) in Chickpea (Cicer arietinum), confirming these results. According to HPLC results; ratio of catechin was higher at shoot part of plants in both years, best results were obtained from control, A.L and A.C. treatments. Contents of caffeic acid, chlorogenic acid and epicatechin were higher at shoot part of plant in the first year. In general, best results of them obtained from control, A.L and A.C. treatments. Ferulic acid content was high at shoot in the first year with P.F and G.I. treatments. Ratio of Quercetin was high in root part of plant in the first year with A.C. treatment. These results displayed the influence of plant age and plant parts on the biochemistry of caffeic acid derivatives. These findings were also reported by Montanari et al. (2008). The results of this trial and other author's reports demonstrated that application of biological fertilizers is a good option for improving quantitative and qualitative yields of purple coneflower. Over the past few decades, the application of chemical materials in agriculture has led to several environmental issues such as contamination of water sources, inferior quality of agricultural crops, reduced biodiversity, genetic erosion, pest resistance and reduced soil fertilization (Sharma, 2002). Consequently, sustainable agriculture has been introduced in order to find a solution for these plagues. In most regions where the Green Revolution had increased yields there were negative environmental impacts such as pollution of water and soils because of pesticides, chemical fertilizers, and heavy metals.

In conclusion, Azospirillum lipoferum (AL) and Azotobacter chrococum (AC) were best results as chemical fertilizers for caffeic acid derivatives of Echinacea purpurea. Biological fertilizers, in some cases as replacements and in most cases as supplements for chemical fertilizers can assure the stability of the agricultural production.

\section{Acknowledgements}

This work was supported by Research Fund of Cukurova University (Project No: ZF2012D14). The authors would like to gratefully acknowledge all the members of Department of Horticulture, University College of Agriculture and Natural Resources, University of Tehran, for providing the facilities to carry out this work and for their suggestions. In addition, it can be appreciated to Agriculture of Research, Education and Extension Organization (AREEO), Iran, for providing Laboratory facilities.

\section{References}

Aghalikhani, M. A., Iranpoor, A., \& Naghadi Badi, H. (2013). Changes in agronomic and phytochemical yields of Echinacea purpurea L. as affected by urea and biological fertilizers. Journal of Medicinal Plants, 46, 121-136.

Banchio, E., Bogino, P. C., Santoro, M., Torres, L., \& Zygadlo, J. (2010). Systemic induction of monoterpene biosynthesis in Origanum majoricum by Soil Bacteria. Journal of Agricultural and Food Chemistry, 58, 650-654. https://doi.org/10.1021/jf9030629

Bauer, R., \& Remiger, P. (1989). TLC and HPLC analysis of alkamides in Echinacea drugs. Planta Medica, 55, 367-371. https://doi.org/10.1055/s-2006-962030 
Berbec, S., Krol, B., \& Wolski, B. (1998). The effect of soil and fertilization on the biomass and phenolic acids content in coneflower (Echinacea purpurea Moench.). Herba Polonica, 44, 397-402.

Bodinent, C., Lindequist, U., Teuscher, E., \& Freudenstein, J. (2002). Effect of an orally applied herbal immunomodulator on cytokine induction and antibody response in normal and immunesuppressed mice. Phytomedicine, 9, 606-613. https://doi.org/10.1078/094471102321616418

Chen, J. H. (2006). The combined use of chemical and organic fertilizer and/or biofertilizer for crop growth and soil fertility (pp. 1-11). International Workshop on Sustained Management of the Soil-Rhizosphere System for Efficient Crop Production and Fertilizer Use, October 16-20, 2006, Bangkok, Thailand.

El-Sayed, A. A, Shalaby, A. S, El-Hanafy, H., \& El-Razik, T. A. (2012). Effects of chemical fertilizers on growth and active constituents of Echinacea paradoxa L. plants. Journal of Horticultural Science \& Ornamental Plants, 4, 125-133.

Kapoor, R., Giri, B., \& Mukerji, K. G. (2002). Glomus macrocarpum, a potential bioinoculant to improve essential oil quality and concentration in dill (Anethum graveolens L.) and carum (Trachyspermum ammi L. Sprague). World Journal of Microbiology and Biotechnology, 18, 459-463. https://doi.org/10.1023/ A:1015522100497

Khaosaad, T., Vierheilig, H., Nell, M., Zitterl-Eglseer, K., \& Novak, J. (2006). Arbuscular mycorrhiza alters the concentration of essential oils in oregano (Origanum sp., Lamiaceae). Mycorrhiza, 16, 443-446. https://doi.org/10.1007/s00572-006-0062-9

Koşar, M., Kafkas, E., Paydaş, S., \& Başer, K. H. C. (2004). Phenolic composition of strawberry genotypes at different maturation stages. Journal of Agricultural and Food Chemistry, 52, 1586-1589. https://doi.org/ 10.1021/jf035093t

Kumar, K. M., \& Ramaiah, S. (2011). Pharmacological importance of Echinacea purpurea. International Journal of Pharma and Bio Sciences, 2, 304-314.

Malik, A. A., Suryapani, S., \& Ahmad, J. (2011). Chemical vs organic cultivation of medicinal and aromatic plants: the choice is clear. International Journal of Medicinal and Aromatic Plants, 1, 5-13.

Montanari, M., Degl'innocenti, E., Maggini, R., Pacifici, S., Pardossi, A., \& Guidi, L. (2008). Effect of nitrate fertilization and saline stress on the contents of active constituents of Echinacea angustifolia DC. Food Chemistry, 107, 1461-1466. https://doi.org/10.1016/j.foodchem.2007.10.001

Omidbaigi, R. (2013). Production and Processing of Medicinal Plants (Volume 4). Tehran: Beh Nashr Publication.

Sharma, A. K. (2002). Biofertilizers for Sustainable Agriculture (p. 407). Agro-Bios, India.

Subba Rao, N. S. (1993). Biofertilizers in Agriculture and Forestry (p. 242). Oxford and IBH Publishing Co. PVT. Ltd., New Delhi.

Tabrizi, L. (2007). Measuring the ecological characteristics of Thymus transcaspicus in natural habitats and evaluating the possibility of its domestication for low-input systems ( $\mathrm{PhD}$ thesis, Department of Agronomy and Plant Breeding, Ferdowsi University of Mashhad).

Taie, H. A., El-Mergawi, R., \& Radwan, S. (2008). Isoflavonoids, flavonoids, phenolic acids profiles and antioxidant activity of soybean seeds as affected by organic and bioorganic fertilization. American-Eurasian Journal of Agricultural \& Environmental Sciences, 4, 207-213.

Wu, C. H., Murthy, H. N., Hahn, E. J., Lee, H. L., \& Paek, K. Y. (2008). Efficient extraction of caffeic acid derivatives from adventitious roots of Echinaceae purpurea. Czech Journal of Food Sciences, 26, 254-258. https://doi.org/10.17221/1120-CJFS

\section{Copyrights}

Copyright for this article is retained by the author(s), with first publication rights granted to the journal.

This is an open-access article distributed under the terms and conditions of the Creative Commons Attribution license (http://creativecommons.org/licenses/by/4.0/). 